\title{
Blockchain Technology - Current Status, Challenges and Perspectives in Tax and Customs Law
}

\author{
Ladislav Hrabčák, ${ }^{*}$ Monika Stojáková**
}

\begin{abstract}
* Ladislav Hrabčák, Mgr., Internal PhD student of Pavol Jozef Šafárik University in Košice, Faculty of Law, Department of Financial Law, Tax Law and Economy. (e-mail: ladislav.hrabcak@student.upjs.sk)

** Monika Stojáková, JUDr., Internal PhD student of Pavol Jozef Šafárik University in Košice, Faculty of Law, Department of Financial Law, Tax Law and Economy. (e-mail: monika.stojakova@student. upjs.sk)
\end{abstract}

\begin{abstract}
One of the hallmarks of the $21^{\text {st }}$ century society is rapid technological progress. It must be addressed by national legal systems, which is another theme discussed in this article. Blockchain technology is one of the most current issues, not only in information technology, but also in law. This paper aims to assess the current legal situation and to reflect on the challenges and perspectives that are undoubtedly related to Blockchain, as it focuses on tax and customs law. Whether Blockchain is capable of contributing to more efficient tax and customs collection is a fundamental hypothesis that we will attempt to confirm or refute.
\end{abstract}

Keywords: Blockchain; tax law; customs law; taxes; customs

\section{Introduction}

The Blockchain technology was birthed in 2008, when a person under the pseudonym Satoshi Nakamoto ${ }^{2}$ introduced an alternative payment system in the document called Bitcoin: A Peer-to-Peer Electronic Cash System. The idea of the Bitcoin's author and developer was initially not embraced by society. The change occurred only at the turn of 2017 and 2018 with a rapid increase in the value of cryptocurrencies, although it could be perceived more as the motivation of most entities to engage in speculative buying and selling virtual currencies ${ }^{3}$ to appreciate their money rather than to show interest in the technology itself.

It is an issue which has been unexplored, and unregulated by legislation. National parliaments have adopted certain legislations with substantial delay, and only due to the increasing value of cryptocurrencies, since it became a prospect of taxation. The concept of "virtual currency" has been applied in Slovak law since January 1, 2018, when the legislature began taxing income linked to cryptocurrency operations.

We can see that the legal systems of the individual states limit their scope mostly to regulating one specific way of using Blockchain, namely cryptocurrencies (in particular their taxation), which relate to their cautious approach to modern technologies, and their lack of readiness to use it potentially in the public sector. It is the positive way of using Blockchain we have set out to highlight in the following text of this paper, which aims to assess the 
current legal status of the technology and to reflect on the challenges and perspectives that are undoubtedly related to Blockchain, as it focuses on tax and customs law.

\section{Technological and Legal Aspects of Distributed Ledger, Blockchain and Smart Contracts}

\subsection{Distributed Ledger Technology (DLT)}

Before we elucidate the Blockchain technology, we must first briefly attend to the "distributed ledger technology" (hereinafter: DLT), since Blockchain represents the most renowned DLT. It is a concept that is broader than the concept of Blockchain. This term is so specific that there is no equivalent denotation for it in the Slovak language without raising certain reservations.

With some measure of generalisation and imprecision, DLT can be defined as a technology, which allows computers in various locations to propose and verify transactions, as well as update the records in the network in a synchronised fashion. ${ }^{4}$

On the whole, DLT represents a way, which enables chronologically arranged information to propagate throughout the entire network. Its defining attribute revolves around information that is cryptographically locked and retroactive changes that are not possible. Another significant aspect is storing information in a decentralised way.

The above is of course also valid for the Blockchain technology with features which make it unique in relation to the DLTs. The most significant difference between the two lies in storing information about potential transactions in Blockchain into blocks that gradually interconnect. It is a quality which every DLT need not have. The following section of the article is dedicated to Blockchain.

\subsection{Blockchain technology}

Some authors consider Blockchain to be both a technology as well as a strategy, which the states can use to provide services in a transparent, effective and decentralised fashion. ${ }^{5}$ We can agree with this opinion and immediately list examples of multiple states which have already adopted the use of the Blockchain technology in the public sector. ${ }^{6}$

We are going to attempt to elucidate the concept of Blockchain in several remarks. The previously presented information makes it apparent that Blockchain is a specific type of a distributed network, in which the exchange transactions are gradually classified into blocks that are mutually interconnected and invariably recorded within the network.?

Technically speaking, there are 3 types of computers involved in Blockchain as follows:

1. nodes - which preserve the entire Blockchain and perceive all transactions, including their histories 
2. miners - who verify the authenticity of the executed transactions via the dedicated technology, and

3. clients

To get a better grasp of how the technology works, Figure 1 models a transaction in Blockchain.

\section{HOW BLOCKCHAIN WORKS}

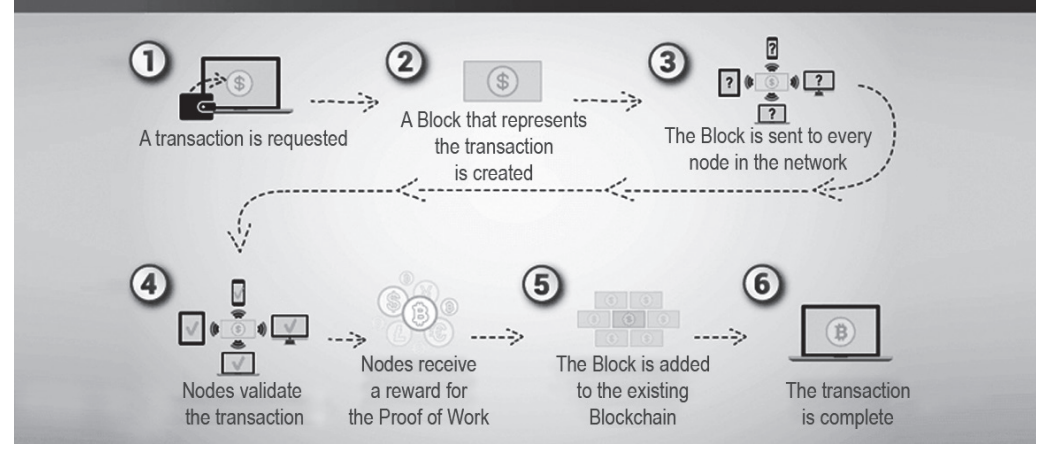

Figure 1 .

Source: www.zignuts.com/blogs/how-blockchain-architecture-works-basicunderstanding-of-blockchain-and-its-architecture $/{ }^{8}$

Blockchain is a legally unregulated technology, which can be attested by the example of the Slovak Republic. In theory, Blockchain is usually compared to a general ledger, database, or a computer program. It is however questionable, whether this technology meets the attributes of at least some of the listed concepts, which have found its place in the legal order of the Slovak Republic.

Most often, Blockchain tends to be likened to a general ledger, namely to an accounting journal. ${ }^{9}$ Although in Act no. 431/2002 Coll. on Accounting as amended, ${ }^{10}$ there is no legal definition of these concepts, it is possible to perceive the likeness in the way accounting is done in the accounting journal. The individual accounting entries are arranged chronologically, which proves accounting of all accounting cases in the accounting period (Act No. 431/2002, s. 12 (1) Coll. on Accounting, as amended). ${ }^{11}$ To some extent this comparison can be accepted with one exception. Our reservation is rooted in the fact that Blockchain allows for virtually endless chaining of new and new blocks and is not confined to a limited period such as the accounting period for an accounting journal. ${ }^{12}$ In contrast to an accounting journal, information recorded in Blockchain is virtually immutable, which is an advantage to states.

Another concept which Blockchain is compared to is a database. Pursuant to s. 130 (1) of Act no. 185/2015 Coll. on Copyright as amended ${ }^{13}$ (hereinafter: Copyright Act), a database is: "...a collection of mutually independent works, data, or other mutually independent materials which are systematically or methodically arranged and individually 
accessible by electronic or other means regardless of the form of its expression." It is clear from this definition that it serves a specific piece of legislation, but by generalising it, it is also possible to arrive at certain characteristics that can subsequently be confronted with the properties of Blockchain technology. The content of the database, as it follows from the respective definition, does not necessarily have to include only copyrighted works, but also other elements that are not copyrighted works or are even excluded from copyright protection. ${ }^{14}$ Blockchain also shares this property since different types of data can be stored within this "database". ${ }^{15}$ Since the element of creativity is absent in the arrangement of the data in question, it can be ruled out that Blockchain carries the attributes of an author database. However, we might wonder whether Blockchain is a so-called unauthorised database where a substantial contribution of an entity to the acquisition, verification or presentation of the database content is important. ${ }^{16}$ This question can also be answered in the negative. Blockchain technology is an open source, ${ }^{17}$ which means it is available to virtually anyone. Based on the above, Blockchain cannot be a database in the sense of the Copyright Act.

Blockchain technology does not carry the features of a computer program either. Here, too, the provisions of the Copyright Act are useful. A computer program "...is a set of commands and instructions expressed in any form, which is used directly or indirectly in a computer or similar technical device..." Also significant here is the conclusion of the referenced provision: "...if it is a result of the author's intellectual activity (Act No. 185/2015, s. 87 (1). Coll. on Copyright as amended"). ${ }^{18}$ This condition is absent in this case. There are also information technology reservations in relation to this comparison but we will not discuss these in detail.

We can see that Blockchain technology is somewhat in a vacuum in the legal conditions of the Slovak Republic, much like in most countries. Due to its peculiarities, it cannot be compared to any of the presented concepts, even if it is closest to an accounting journal.

This technology is in principle considered safe because thousands of independent miners ${ }^{19}$ participate in the network to verify individual transactions (see above), and therefore its use in the public sector can be considered. It connects to the following characteristic features of Blockchain:

1. availability - it is a non-patented technology, allowing for a wider range of application

2. decentralisation and security - data control is transferred from centralised institutions to individuals

3. transparency - information is easily traceable and retrospective change is not possible

4. distribution - $\mathrm{P} 2 \mathrm{P}^{20}$ systems hinge on the fact that all information is sent to all active nodes in the network which ensures fast and automatic availability of information to users

States will first have to deal with the issue whether the state's local Blockchain can be as secure as the one used for cryptocurrencies and whether it is global in nature. In principle, it is essentially far easier to compromise Blockchain that exists within a single state than the worldwide Blockchain. Another question raised revolves around ways to strengthen 
the position of the state, as the use of this technology weakens $i t,{ }^{21}$ while the possibility of avoiding foreign influence remains an equally important issue if a person or a group of persons gained control over the absolute majority of the miners' network, in which they could then arbitrarily falsify transactions without being revealed. These are only some of the pitfalls associated with this modern achievement.

\subsection{Smart contracts}

Smart contracts serve as an example of Blockchain's use that is not limited to cryptocurrency. Generally, smart contracts are agreements in the form of computer programs. The basic objective of smart contracts is to eliminate the need for an intermediary and at the same time to contribute to simplifying the execution of online transactions between anonymous participants.

As far as the definition of smart contracts is concerned, they can be defined as agreements between parties, which are stored as computer codes recorded in Blockchain that ensures independent and automatic execution when pre-agreed conditions are fulfilled. ${ }^{22}$ This definition yields certain defining features, which are:

1. terms of contract in source code - use of programming language in contrast to standard contracts using a common language ${ }^{23}$

2. storing source code on the Blockchain platform - this platform ensures durability and non-reversibility of a smart contract ${ }^{24}$

3. independence - the will of the parties is required initially, but it is no longer needed after the conclusion of the smart contract

4. self-execution, after fulfilment of predetermined conditions, is related to the previous quality and therefore smart contracts are described by some authors as executors of themselves ${ }^{25}$

We could undoubtedly include its unregulated nature as another defining feature, since this is an issue that the legal norms in the legal systems of states do not consider.

It is also important to deal with the question of whether smart contracts can be regarded as contracts in the true sense of the word. There is no consensus among law theorists on this issue. Many have reservations in relation to the designation of smart contracts as "smart", as they are merely executors of what is contained in the source code. ${ }^{26}$

We are going to point out to the example of the Slovak law to elucidate whether smart contracts are contracts in the proper sense of the word. "The contractual relationship is a legal relationship that gives the creditor the right to performance (receivable) from the debtor and the debtor becomes obliged to fulfil the obligation (Act No. 40/1964, s. 488 Coll. of the Civil Code as amended)". ${ }^{27}$ It is a very broad definition of a contractual relationship, but more important to us is that the smart contract is certainly a legal fact that gives rise to a legal relationship between the contracting parties. In accordance with that provision, therefore, the obligation is subject to certain performance. The will of the contracting parties is required initially, but it is subsequently no longer necessary, and therefore the debtor is essentially unable to avoid the fulfilment of his obligation. The essential fact here, 
however, is that the contracting parties show their willingness to be bound by it which makes the views in theory, whether legal obligations in the true sense of the word arise here, unfounded. ${ }^{28}$

It is questionable whether a smart contract can be regarded as a comprehensive contract or an agreement on the way of its performance which will form a part of a comprehensive contract. ${ }^{29}$ Regardless, we agree that in the event of damage, it is possible to file a claim in court, and also, that if one of the parties is a consumer, the consumer protection regulation applies. ${ }^{30}$

Their use in practice could follow this course:

1. the contracting parties set the terms and conditions

2. the terms and conditions must then be written in computer code

3. the code is stored in Blockchain and cannot be changed from now on

4. the conditions are fulfilled, the contract will execute itself

In comparison with traditional contracts, smart contracts are characterised by the following aspects:

1. they are completely digital

2. they are "self-executing" in nature, and

3. the code itself defines the obligations of the contracting parties

Smart contracts are a very interesting idea, but they have not yet had much success in practice. However, it is more than likely that future is bright for smart contracts, which is why the legislators will have to deal with this issue. The use of Blockchain and smart contracts is possible also in tax and customs law, which we are going to point out further on.

\section{A New Tool for more Efficient Tax and Customs Collection?}

Several authors have already pointed out in their publications that Blockchain can also be used in the public sector. ${ }^{31}$ This can be explored in several directions, but we will, because of the limited scope of the paper, consider its use in the following situations.

\subsection{Use of Blockchain to eliminate tax and customs fraud}

Value added tax (hereinafter: VAT), as a general indirect consumer $\operatorname{tax},{ }^{32}$ is a traditional part of the tax systems of the EU Member States. While it is true that this tax involves certain issues, it is the most profitable tax ever. ${ }^{33}$ On the other hand, VAT evasion climbed across the EU in 2016 to $€ 147.1$ billion, ${ }^{34}$ which is in fact an alarming figure. This situation can also be attributed to cross-border intra-EU trade as it is exempt from VAT in the current legal situation. Although this exemption is planned to be abolished in the context of the upcoming reform of the EU VAT system, Blockchain technology is also a promising tool (especially in the future) in eliminating VAT evasion. 
Here, we will try to briefly explain what the MTIC fraud entails (from Missing trader intra-community fraud), and how it could be countered by using this modern tool. In general, MTIC fraud is an abuse of the VAT system in cross-border trade. Figure 2 models how such fraud could work.

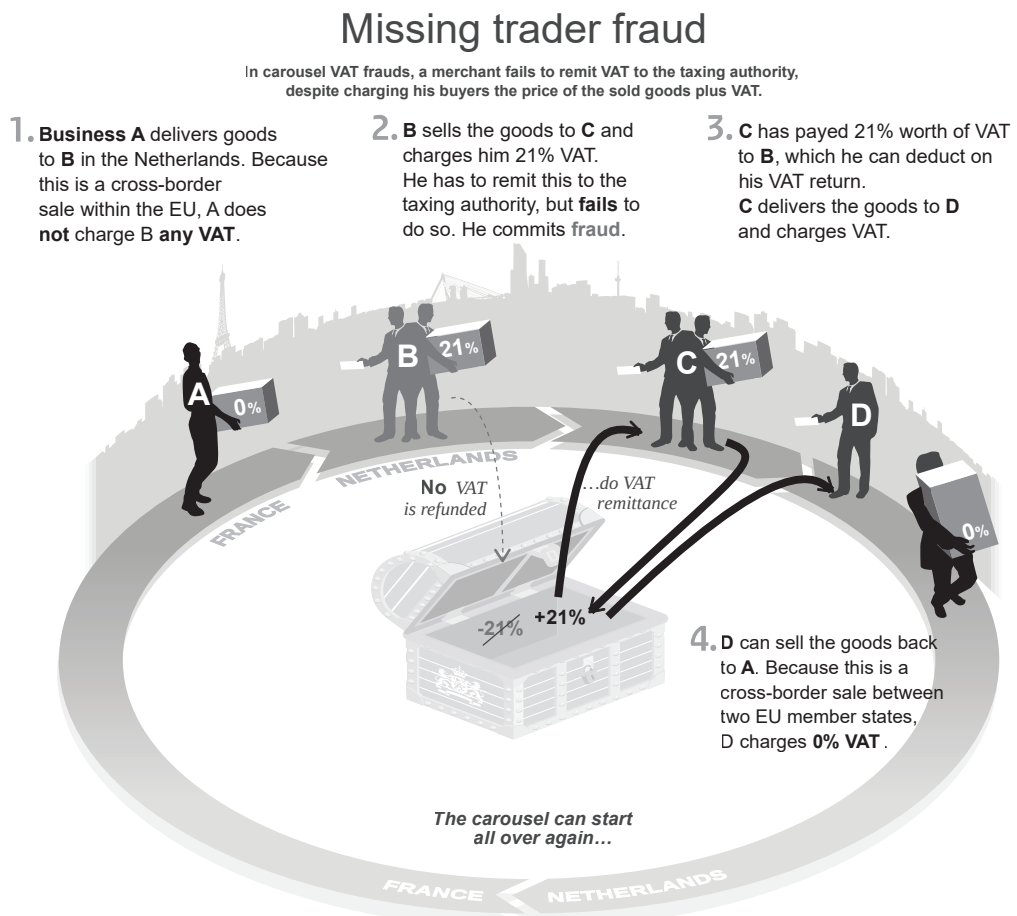

Figure 2.

Source: https://en.wikipedia.org/wiki/Missing_trader_fraud\#/media/File:Carrouselfraude.svg 35

Person A from one member state delivered goods to person B in another member state. This trade will not be subject to VAT as it qualifies for a VAT exemption. Subsequently, person B sold the goods with applied VAT to person $\mathrm{C}$ from another member state. Person $\mathrm{B}$, however, did remit the VAT to the tax authority, thereby committing fraud, but person $\mathrm{C}$ deducted it on their VAT return. Then, person $\mathrm{C}$ delivered the goods to person $\mathrm{D}$, who sold it back to person A. Such a chain can be repeated practically indefinitely. In theory, this situation is commonly referred to as carousel fraud, or carousel chain. ${ }^{36}$

According to some estimates, applying the potential of Blockchain technology could reduce VAT evasion by EUR 50-60 billion per year. ${ }^{37}$ It could be possible by using a multilateral smart contract to which the seller, the buyer, the competent tax authority, and the banks of the seller and the buyer would be parties. It is the buyer's bank that will have a significant role in this multilateral relationship, since it will "redistribute" the buyer's payment by transferring VAT to the tax authority's account and the purchase price, less 
VAT, to the seller's account. In this way, it would be possible to eliminate the risk of error by taxpayers, and, also to reduce the extent of fraudulent action. Such an automated process would also be advantageous because the information about the entire transaction would be recorded in Blockchain, in an immutable and continuous manner.

From a legal point of view, the nature of the legal relationship arising from a multilateral smart contract is also an interesting issue. Here we get to a specific situation where the state is also represented by a particular tax authority. It becomes permeated by public law elements and the legal relationship becomes hybrid.

In contrast to the current situation, final VAT clearance would no longer lie with the taxpayers. ${ }^{38}$ Based on this principle, each company's VAT input and output balance would be kept by the tax authorities, and its new information updates would be continuously recorded in Blockchain. Technically, entrepreneurs will need to be linked to a "transaction register".

As it is a modern technology, there are some unanswered questions, or pitfalls. One is the amount of data that would be recorded. It is questionable whether Blockchain is able to function smoothly even under an extreme load and overload of business transactions. It is also questionable how to protect this confidential data from various hacker attacks, as practice has shown us that even these are not out of the question.

If the EU member states are interested in putting this technology into practice, it will also be very difficult to deal with the user interface, taking into account the number of member states and the number of entities operating in their territory. This system must also take into account the modification of existing registers in the individual countries, or whether eIDAS must be compatible ${ }^{39}$ to be applicable under the current legal situation.

In addition to tax law, the concept of Blockchain has not gone unnoticed also in customs administration. Meanwhile, it is clear, that information technology is taking on an increasingly important role in modern customs administration, but the priorities, expectations, experience, capacities and resources of individual customs administrations vary widely. Customs administrations fight fraud by demanding a high degree of accounting and reporting accuracy to support indirect taxation and customs declarations. The so-called "blocking technology" is also a step forward for customs in the $21^{\text {st }}$ century, as it offers several opportunities for it, from collecting accurate data to automatically detecting customs evasion and fraud, as well as collecting customs. Where block chains allow sensitive or valuable data to be transmitted with accuracy and trust, it is no wonder that they are becoming increasingly common in everyday business processes.

The customs procedure takes place in certain phases - from the start of a customs procedure, through the identification of the documents for the decision, to the issuance of the substantive decision. ${ }^{40}$ It is very important in the customs procedure to prove the veracity, credibility and completeness of all the documents required for the goods. The time and cost of clearing goods for import or export entails a significant financial burden on trade because of the number of permits necessary to import or export goods. These are various permits, licenses, phytosanitary certificates, and others that are required for health, human, animal or plant safety. The so-called "arbitrator" in border trade is the customs administration whose task is to ensure that all such authorisations are duly obtained, valid and the goods legally declared and that all regulatory requirements are met. In customs 
administration, the documents, which describe or should describe the nature of the goods, and whether the goods comply with the required standards, play an important part. What if all steps in the supply chain from origin to destination were contained in Blockchain?!

Customs block chains would allow for comprehensive management of product life cycle data by providing a common platform where manufacturers, laboratories, logistics operators, regulators and consumers can fully access all related information such as demonstration, testing, certification and licensing. Blockchain technology would ensure that the electronic certificate is appropriately and properly issued and subsequently digitally signed by a valid regulatory/issuing agency. At the same time, the certificate would be protected from any risk of modification, misuse or tampering with its content. Consequently, it would only have to be verified whether there is any discrepancy between the data submitted by traders and the data that has been updated repeatedly in the public ledger. Depending on the unchangeable and trustworthy data that the customs authorities might have in the private sector network, they could distinguish between illegitimate and legitimate trade as much as possible without relying on their traditional risk management technique.

Blockchain technology is based on cryptographic evidence instead of trust, allowing parties to trade directly with each other without the need for a trusted third party. The truthfulness and reliability of the information contained in the documents is essential, but it is difficult to achieve certainty, as the necessary information is often provided by third parties and can be obtained from different systems. Errors can lead to penalties, loss of opportunities and costly delays in cross-border goods transport. One of the advantages of Blockchain technology is that there is no intermediary which means that decentralised ledgers reduce the need for trust based on third-party transaction verification, i.e. intermediaries, from transactions. The speed, accuracy and transparency of Blockchain could help alleviate this burden for taxpayers by reducing the risk of fraud. Traders are often obliged to provide additional information, documents (e.g. on the origin of goods), or documents which enable them to benefit from concessions or reductions in customs duties (e.g. through a free trade agreement). However, if these items were kept automatically in the block chain and the customs authorities had access to the chain, they could verify with complete accuracy the origin and nature of the goods at each stage of the chain. In short, the documentation and communication required for the transport of goods between continents would be largely automated and, at that, done with accuracy, security and reduced time and costs associated with these tasks. The launch of Blockchain would also significantly reduce the costs associated with documenting each step of customs authorities, the logistics process, transparency in terms of shipment delivery and the transfer of funds. ${ }^{41}$

Blockchain is a step forward in customs and trade that want more efficiency in their business. More specifically, the technology will help to ensure the customs security of legitimate trade, while also calling on customs and commercial authorities to simplify their tasks (often called "bureaucracy") that have been required to comply. Undoubtedly, Blockchain technology is a huge leap for customs in the $21^{\text {st }}$ century. 


\subsection{Blockchain technology and real estate registration for tax purposes}

Local taxes, including real estate tax, can be considered a relatively new but stable instrument in our tax system, even though their existence was already foreseen by the Slovak National Assembly Act no. 369/1990 Coll. on Municipal Establishment, as amended, ${ }^{42}$ but most of all, Article 59(1) of the Constitution of the Slovak Republic ${ }^{43}$ no. 460/1992 Coll., as amended. ${ }^{44}$ Local taxes are taxes that citizens pay to their municipality to finance a wide range of public goods. However, with regard to local taxes, all citizens' taxes must be manually registered through private entities, logged in a database where the information is collected by the tax officials of the municipality. The citizens paying these taxes then "pass" through the banks to make the payment. All these methods are centralised and they are not automated.

Blockchain enables a decentralised and distributed system that allows you to track paid taxes, streamlines, and automates the process itself, and brings confidence to the system. The Real Estate Cadastre is a formal system that provides identification and location of real estate and records of the past, as well as current data relating to the respective piece of real estate. Many public services rely on data stored in the Real Estate Cadastre (hereinafter: REC). The main issues which the REC systems still face in many countries relate to the accuracy of the data stored in the REC and the effectiveness of the REC systems. Although all data stored in this information system should be credible and correct, this is not the case - inaccuracies or errors are usually the result of errors that occurred in the digitisation process. The Land Register provides answers to questions about who owns certain property and what legal document establishes the title. Cadastre is an official record of real estate data in a particular area, which is also significant for tax purposes.

Blockchain used for property records could be potentially applicable via smart contracts. In fact, smart contracts are written and stored in Blockchain (see above). Because they are stored in Blockchain, they are also immutable, so it should not be possible for anyone to have access to smart contract data stored in Blockchain technology. The simplest example could be that as soon as there is a change of ownership registered in the Land Register, the other involved institutions should be automatically informed of the change. For example, the tax administrator in whose district the property is located, could be automatically informed, but also, for example, utility companies that are entitled to be informed of a change in billing information from a certain date to another natural or legal person. ${ }^{45}$

At present, it is not unusual for computer programs to evaluate images. We also see the potential of Blockchain technology in synergy with other databases, by linking them together to automatically compare the real estate data recorded in Blockchain with the data obtained from satellite imagery. This could prevent (even by the verification of facts by local investigation) both illegal construction and the related tax evasion on real estate tax. 


\section{Conclusion}

This paper aimed to confirm or refute the basic hypothesis - whether Blockchain technology is capable of contributing to more efficient tax and customs collection. Based on what we have presented here, we must conclude that the hypothesis has been confirmed.

Undoubtedly, Blockchain is an instrument (among others, also in the fight against tax and customs evasion) that the governments of individual member states can count on in the future. However, as things stand, there are a number of issues (both legal and technical), such as:

- protection of confidential data from hacking attacks

- respect for modifications in the existing registers and lists for tax purposes in the individual Member States

- eIADAS compatibility, and others

These must first be answered to make use of Blockchain in the public sector and to assist the states.

While lack of legal regulation makes this technology attractive to many, it is necessary for both national parliaments and the European Parliament to address this issue and establish minimum standards to create a legal framework for the use of Blockchain technology in the public sector.

It will also be difficult to find a suitable model, or Blockchain "public" architecture, which could be put into practice, not only at the European or national level, but also at the level of municipalities and cities. This need has already been identified by the European Parliament and, to this end, it has asked the European Commission, as well as the relevant working groups, in its Resolution of 24 November 2016 on towards a definitive VAT system and combating VAT fraud [2016/2033 (INI)], ${ }^{46}$ to address the issue of "digital technologies", which should contribute to "filling" the VAT gap.

Only the future will show how the regulatory challenges of the EU and the member states will be dealt with and whether we can use modern technologies to our advantage or they will engulf us. 


\section{References}

1 This paper was created as a partial output of the project solution vvgs-2019-1068 "Blockchain Technology as a Factor Affecting the Current Form of Law" and VEGA 1/0846/17: "Implementation of the Initiatives of the EU Institutions in Direct and Indirect Taxation and Their Legal Budgetary Implications".

2 Satoshi Nakamoto, Bitcoin: A Peer-to-Peer Electronic Cash System, 2008, https://bitcoin.org/bitcoin.pdf (accessed 25 August 2019).

3 The concepts of "virtual currency" and "cryptocurrency" are not identical, but are used interchangeably for the purposes of this paper.

4 David Allessie, Maciej Sobolewski, Lorenzino Vaccari, Blockchain for Digital Government, Publications Office of the European Union (Luxemburg, 2019). https://doi.org/10.2760/942739

5 Zdenka Poláková, Peter Rakovský, Blockchain technológie - regulačné výzvy a príležitosti [Blockchain Technologies - Regulatory Challenges and Opportunities], 82 et seq., in Zbornik z medzinárodnej vedeckej konferencie Bratislavské právnické fórum 2018 [Collection of Papers from the International Academic Conference Bratislava Legal Forum 2018] (Bratislava, Univerzita Komenského v Bratislave, 2018).

6 The Scandinavian countries are pioneers here, while Estonia is definitely an interesting example of modern technology application within parameters similar to the Slovak Republic.

7 David Allessie, Maciej Sobolewski, Lorenzino Vaccari, Blockchain for Digital Government, Publications Office of the European Union (Luxemburg, 2019). https://doi.org/10.2760/942739

8 How blockchain architecture works? Basic Understanding of Blockchain and its Architecture, www.zignuts.com/ blogs/how-blockchain-architecture-works-basic-understanding-of-blockchain-and-its-architecture/ (accessed 25 August 2019).

9 Zdenka Poláková, Peter Rakovský, Blockchain technológie - regulačné výzvy a príležitosti [Blockchain Technologies - Regulatory Challenges and Opportunities], 82 et seq., in Zbornik z medzinárodnej vedeckej konferencie Bratislavské právnické fórum 2018 [Collection of Papers from the International Academic Conference Bratislava Legal Forum 2018] (Bratislava, Univerzita Komenského v Bratislave, 2018).

10 Act no. 431/2002 Coll. on Accounting, as amended.

11 Ibid.

12 Of course, by this we do not mean an inability to check the individual transactions in another accounting period, as taxpayers are required to keep their accounting records for the period prescribed by law, but we wanted to point to the content of Blockchain and the accounting journal.

13 Act no. 185/2015 Coll. on Copyright, as amended.

14 Peter Vojčík et al., Právo duševného vlastnictva [Intellectual Property Law] (Plzeň, Aleš Čeněk, 2014).

15 Ladislav Hrabčák, Výzvy pre daňové právo v podobe Blockchain technológie [Challenges for Tax Law in the Form of Blockchain Technology] in Zbornik príspevkov zo 6. ročnika Jarnej internacionalizovanej školy doktorandov UPJŠ 2019 [Proceedings of the $6^{\text {th }}$ Spring Internationalized School of PhD Students UPJŠ 2019] (Košice, ŠafárikPress, 2019).

16 Peter Vojčík et al., Právo duševného vlastníctva [Intellectual Property Law] (Plzeň, Aleš Čeněk, 2014).

17 The "open source" designation generally means that it is a computer software with so-called open source code.

18 Act no. 185/2015 Coll. on Copyright, as amended.

19 Of course, it also depends how consensus is achieved in the relevant network. This is typical of the Proof of Work method. See Ladislav Hrabčák, Výzvy pre daňové právo v podobe Blockchain technológie [Challenges for Tax Law in the Form of Blockchain Technology], 60, in Zbornik prispevkov zo 6. ročnika Jarnej internacionalizovanej školy doktorandov UPJS 2019 [Proceedings of the $6^{\text {th }}$ Spring Internationalized School of PhD Students UPJŠ 2019] (Košice, ŠafárikPress, 2019).

20 Peer-to-peer phrase, which originates in English, refers to a decentralised communication model.

21 The weakened position of the state lies in the fact that Blockchain is decentralised in nature and as such is somewhat elusive to the state's full control. 
22 Alexander Savelyev, Contract Law 2.0: «Smart» Contracts as the Beginning of the End of Classic Contract Law (Moscow, National Research University Higher School of Economics, 2016). https://doi.org/10.2139/ssrn.2885241

23 In judicial practice, this could cause considerable complications due to the lack of knowledge of the programming language by judges.

24 Theoretically, changes could be made by concluding a new smart contract (but without affecting the original contract) or if this option was directly incorporated in the source code.

25 Adam Zábranský, Úvod do práva smart kontraktũ - část 1 [Introduction to the Law of Smart Contracts - Part 1], www.epravo.cz/top/clanky/uvod-do-prava-smart-kontraktu-cast-1-109049.html (accessed 10 August 2019).

26 Stephen McJohn, Ian Mcjohn, The Commercial Law of Bitcoin and Blockchain Transactions (2016).

27 Act no. 40/1964 Coll. the Civil Code, as amended.

28 Alexander Savelyev, Contract Law 2.0: «Smart» Contracts as the Beginning of the End of Classic Contract Law (Moscow, National Research University Higher School of Economics, 2016). https://doi.org/10.2139/ssrn.2885241

29 Some academics regard smart contracts as a form of self-help. See Max Raskin, The Law of Smart Contracts (Georgetown Technology Review, 2017).

30 Adam Zábranský, Základni právni aspekty smart kontraktio - část 2 [Basic Legal Aspects of Smart Contracts - Part 2], www.epravo.cz/top/clanky/zakladni-pravni-aspekty-smart-kontraktu-cast-2-109050. html (accessed 10 August 2019).

31 Zdenka Poláková, Peter Rakovský, Blockchain technológie - regulačné výzvy a príležitosti [Blockchain Technologies - Regulatory Challenges and Opportunities], 82 et seq., in Zbornik z medzinárodnej vedeckej konferencie Bratislavské právnické fórum 2018 [Collection of Papers from the International Academic Conference Bratislava Legal Forum 2018] (Bratislava, Univerzita Komenského v Bratislave, 2018).

32 Vladimír Babčák, Dañové právo na Slovensku [Tax Law in Slovakia] (Bratislava, Epos, 2015).

33 Miroslav Štrkolec, Zabezpečovacie inštitúty pri správe dani [Tax Administration Security Institutions] (Košice, Equilibria, 2017).

34 Grzegorz Poniatowski et al., Study and Reports on the VAT Gap in the EU-28 Member States: 2018 Final Report TAXUD/2015/CC/131, https://ec.europa.eu/taxation_customs/sites/taxation/files/vat-gap-fullreport-2019_en.pdf (accessed 13 August 2019). https://doi.org/10.2139/ssrn.3272816

35 Missing Trader Fraud, https://en.wikipedia.org/wiki/Missing_trader_fraud\#/media/File:Carrouselfraude. svg (accessed 13 August 2019).

36 Peter Šamko, Daňové podvodné konania a ich dokazovanie [Tax Fraud and Evidence] (Bratislava, Wolters Kluwer, 2015).

37 David Allessie, Maciej Sobolewski, Lorenzino Vaccari, Blockchain for Digital Government, Publications Office of the European Union (Luxemburg, 2019).

38 Ibid.

39 Petra Krupičková, Smart contract - revoluce v smluvním právu 21. století? [Smart Contract - Revolution in $21^{\text {st }}$ Century Contract Law ?], 26, in Revue pro právo a technologie [Revue for Law and Technology] (Brno, Masarykova univerzita v Brne, 2017). https://doi.org/10.5817/RPT2017-1-2

40 Karin Prievozníková, Colné právo [Customs Law] (Žilina, Knižné centrum, 2008).

41 Monika Stojáková, Eliminácia daňových a colných únikov vplyvom moderných technológií [Elimination of Tax and Customs Evasion due to Available Modern Technologies], 272-285, in Vplyv moderných technológii na právo [Effect of Modern Technologies on Law] (Košice, UPJŠ, 2019).

42 Slovak National Assembly Act no. 369/1990 Coll. on Municipal Establishment, as amended.

43 Constitution of the Slovak Republic no. 460/1990 Coll., as amended.

44 Vladimír Babčák, Daňové právo na Slovensku [Tax Law in Slovakia] (Bratislava, Epos, 2015).

45 Miroslav Stefanović et al., Blockchain and Land Administration: Possible Applications and Limitations, in Proceedings of the $5^{\text {th }}$ International Scientific Conference on Contemporary Issues in Economics, Business and Management EBM 2018 (Kragujevac, Faculty of Economics, University of Kragujevac, 2018).

46 European Parliament resolution of 24 November 2016 on towards a definitive VAT system and combating VAT fraud [2016/2033 (INI)]. 